\section{Merve Demir}

Bournemouth University, United Kingdom

mdemir@bournemouth.ac.uk

ORCID: 0000-0002-7620-9658

\section{Tilak Ginige}

Bournemouth University, United Kingdom

tginige@bournemouth.ac.uk

ORCID: 0000-0002-0650-8468

\section{lain Green}

Bournemouth University, United Kingdom

igreen@bournemouth.ac.uk

ORCID: 0000-0002-0418-3524

https://doi.org/10.26881/gsp.2021.3.08

\title{
Effectiveness of the United Kingdom Soil Protection Laws in Protecting the Ecosystem Service of Carbon Sequestration
}

\section{Introduction}

There is consensus among scientists that greenhouse gas emissions are driving climate change (CC) and current forecasts predict that global temperatures will continue to rise beyond the end of this century. ${ }^{1}$ Consequently, Earth's ecosystems will face increasingly severe challenges due to warming and drying. ${ }^{2}$ Issues are non-exhaustive as predicting the effects on climate and ecosystems are highly complex and uncertain due to the interrelations among Earth's systems.

Even if we manage to achieve net-zero emissions, ${ }^{3}$ impacts of CC will persist for centuries, as there are already high levels of $\mathrm{CO}_{2}$ in the atmosphere; in 2021, atmospheric $\mathrm{CO}_{2}$ reached $\sim 415$ parts per million ${ }^{4}$ and this has a long residence time. The key to reversing increased atmospheric $\mathrm{CO}_{2}$ and its impacts is large scale net removal of $\mathrm{CO}_{2}$ from the atmosphere over a sustained period. ${ }^{5}$ Thus, a two-limb approach to combating $\mathrm{CC}$ is required: cutting down the $\mathrm{CO}_{2}$ emissions and removing the existing $\mathrm{CO}_{2}$ from the atmosphere. ${ }^{6}$

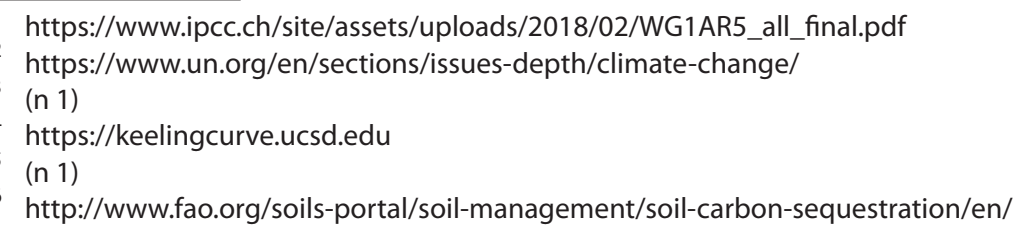




\section{Soil Carbon Cycle}

Carbon sequestration (CS) describes both natural and deliberate processes by which $\mathrm{CO}_{2}$ is either removed from the atmosphere or diverted from emission sources and stored in the ocean and terrestrial environments. ${ }^{7}$ The terrestrial biosphere reservoir contains carbon $(\mathrm{C})$ in organic compounds, living vegetation biomass, soils and the geology. ${ }^{8}$

Globally, soils contain $\sim 2,500$ gigatons of $C$, which amounts to more than three times the amount of $C$ in the atmosphere and four times the amount stored in all living plants and animals. ${ }^{9} \mathrm{UK}$ soils alone contain $\sim 10$ billion tonnes of $\mathrm{C}$, roughly equal to 80 years of GHG emissions. ${ }^{10}$

$\mathrm{CO}_{2}$ is removed from the atmosphere by plant photosynthesis and $\mathrm{C}$ fixed by the plant is cycled through plant tissues, litter and soil C. ${ }^{11} \mathrm{C}$ enters the soil when plants die, through leaf litter fall and root turnover, root exudates, plant residues, microbial residues, and other organic solids. ${ }^{2}$ These materials are consumed by soil organisms (e.g., bacteria, fungi), which respire some of the $\mathrm{C}$ back into the atmosphere, but ultimately transform more recalcitrant forms of $\mathrm{C}$ into soil organic matter (SOM). ${ }^{13}$ SOM is variable in chemical composition, but is comprised of about $50 \%$ organic $\mathrm{C}_{1}^{14}$ containing above three times as much as atmospheric $\mathrm{C}^{15}$

Soil $\mathrm{C}$ can be released back into the atmosphere through respiration by soil microbial, fungi, bacteria, plant and animals over time scales ranging from seconds to millennia. ${ }^{16} \mathrm{CO}_{2}$ as SOM is stored in short-lived stores (leaves and fine roots), and longlived stores (woody stems or as soil C). ${ }^{17}$ If $\mathrm{C}$ is released in a very short time, it cannot be considered as sequestered. An excellent contribution to $\mathrm{CC}$ response is $\mathrm{C}$ storage for long periods. Rich plant diversity ${ }^{18}$ and biodiversity (BD) contribute to extended

\footnotetext{
7 https://pubs.usgs.gov/fs/2008/3097/pdf/CarbonFS.pdf

8 (n 1)

9 T.A. Ontl and L.A. Schulte, "Soil Carbon Storage" (2012) 3 Nature Education Knowledge 35.

10 https://assets.publishing.service.gov.uk/government/uploads/system/uploads/attachment_ data/file/805926/State_of_the_environment_soil_report.pdf

11 Ibidem.

12 K.R. Olson et al., "Experimental Consideration, Treatments, and Methods in Determining Soil Organic Carbon Sequestration Rates" (2014) 78 Soil Sci Soc Am J 348.

13 C. Gougoulias et al., "The role of soil microbes in the global carbon cycle: tracking the belowground microbial processing of plant-derived carbon for manipulating carbon dynamics in agricultural systems" (2014) 94 J Sci Food Agric 2362.

14 D.W. Pribyl, "A critical review of the conventional SOC to SOM conversion factor" (2010) 156 Geoderma 75.

15 R. Lal, "Managing soils for negative feedback to climate change and positive impact on food and nutritional security" (2020) 66 Soil Sci Plant Nutr 1.

16 (n 1 )

17 Ibidem.

18 S. Chen et al., "Plant diversity enhances productivity and soil carbon storage" (2018) 115 PNAS 4027; Y. Yang et al., "Soil carbon sequestration accelerated by restoration of grassland biodiversity" (2019) 10 Nature Communications 718.
} 
periods of CS, especially at local and regional scales. ${ }^{19}$ Soil BD, including viruses, bacteria, fungi, algae, protozoa, mites, nematodes and oligochaete worms, ${ }^{20}$ contributes to soil functioning. ${ }^{21}$ Earthworms are likely to accelerate soil restoration, ${ }^{22}$ fungal to bacterial ratios are ecologically important for $\mathrm{C}$ storage, ${ }^{23}$ and soils with higher fungal to bacterial ratios are characterised by higher $\mathrm{C}$ use efficiencies, ${ }^{24}$ lastly the abundance of soil invertebrates can affect soil structure and $\mathrm{C}$ storage in soil. ${ }^{25}$ Microorganisms determine if fresh $\mathrm{C}$ input is converted into stable SOM or lost as $\mathrm{CO}_{2}{ }^{26}$ To utilise CS and its co-benefits, BD above and belowground must be maintained. ${ }^{27}$

\section{Soil Degradation and Agriculture}

The focus of the present study is agricultural soils. Agricultural practices use $72 \%$ of the UK's land area ( 17.5 million hectares) ${ }^{28}$ and are the bedrock of the UK economy. ${ }^{29}$ These are vital for food production, shaping the landscape and providing important recreational ecosystem services (ES). ${ }^{30}$ Yet, agricultural soils are facing continuing degradation. ${ }^{31}$

Soil degradation represents the loss of soil's intrinsic physical, chemical, and biological qualities, leading to diminution or destruction of crucial functions. ${ }^{32}$ Significant

19 G.F. Midgley et al., "Terrestrial carbon stocks and biodiversity: Key knowledge gaps and some policy implications" (2010) 2 Curr Opin Environ Sustain 264.

20 M. Blouin et al., "A review of earthworm impact on soil function and ecosystem services" (2013) 64 Soil Sci. 161.

21 I. Green et al., "Accumulation of Potentially Toxic Elements in Agricultural Soils" [in:] Environmental Loss and Damage in a Comparative Law Perspective: Attribution, Liability, Compensation and Restoration, eds B. Pozzo and V. Jacometti (Intersentia, Cambridge 2020).

22 S. Boyer and S.D. Wratten, "The Potential of Earthworms to Restore Ecosystem Services After Opencast Mining - A Review" (2010) 11 BAAE 196.

23 F.T. de Vries et al., "Soil food web properties explain ecosystem services across European land use systems" (2013) 110 PNAS 14296; A.A. Malik et al., "Soil Fungal: Bacterial Ratios Are Linked to Altered Carbon Cycling" (2016) 7 Front. Microbiol. 1247.

24 J. Six et al., "Bacterial and Fungal Contributions to Carbon Sequestration in Agroecosystems" (2006) 70 Soil Sci Soc Am J 555.

25 A.J. Franco et al., "Linking soil engineers, structural stability, and organic matter allocation to unravel soil carbon responses to land-use change" (2020) 150 Soil Biol. Biochem. 107998.

26 Y. Rui et al., "Microbial respiration, but not biomass, responded linearly to increasing light fraction organic matter input: Consequences for carbon sequestration" (2016) 6 Scientific Reports 35496.

27 https://rodaleinstitute.org/education/resources/regenerative-agriculture-and-the-soil-carbonsolution

28 https://assets.publishing.service.gov.uk/government/uploads/system/uploads/attachment_ data/file/747210/structure-jun2018prov-UK-11oct18.pdf

29 https://www.countrysideonline.co.uk/food-and-farming/contributing-to-the-economy/

30 https://assets.publishing.service.gov.uk/government/uploads/system/uploads/attachment data/file/741062/AUK-2017-18sep18.pdf

31 https://assets.publishing.service.gov.uk/government/uploads/system/uploads/attachment_ data/file/69261/pb13297-soil-strategy-090910.pdf

32 F.C. Nunes et al., "Soil as a complex ecological system for meeting food and nutritional security" [in:] Climate Change and Soil Interactions, eds M.N.V. Prasad and M. Pietrzykowski (Elsevier 2020). 
causes of degradation of agricultural soils are found in the social, economic, political and cultural context in which farmers operate. ${ }^{33}$ The main objective of agriculture appears as producing more provisioning services, e.g. agricultural products, ${ }^{34}$ failing to reflect the importance of soils' regulating, cultural and supporting services. ${ }^{35}$ Farming has become more intensive for this purpose (e.g., use of heavier machinery, fields increasing in size and maximising yields), causing adverse impacts on the environment. ${ }^{36}$ In a nutshell, farms pollute ground and surface water, air and soils, ${ }^{37}$ affect wildlife and add to sedimentation in lake and rivers. ${ }^{38}$ Intensive tillage, in particular decreases soil C levels, ${ }^{39}$ and pollution can also adversely impact SOM. ${ }^{40}$ The natural process of soil degradation accelerated by anthropological activities, ${ }^{41}$ and several agricultural practices interact with soil threats. ${ }^{42}$

Erosion and pollution are two significant threats that UK soils face and have a direct correlation with the pressures from the farming industry. ${ }^{43}$ Erosion causes nutrient loss, ${ }^{44}$ which leads to a greater need for agrochemicals. To support the increased demand for agricultural products, pesticides, herbicides, ${ }^{45}$ and cheap inorganic fertilisers, ${ }^{46}$ sewage sludge and animal manures/slurries are applied, increasing the levels of potentially toxic elements (PTEs) in soils. ${ }^{47}$ Pollution arises when PTEs are in such amounts that they negatively impact edaphic organisms. ${ }^{48}$ The effects are clearly seen in plant health where the level of PTEs exceeds the plant's tolerance threshold. ${ }^{49}$ Soil microbes, which are central to all life on Earth due to their huge diversity in form

\footnotetext{
33 H. Posthumus et al., "Soil conservation in two English catchments: Linking soil management with policies" (2011) 22 Land Degrad. Develop. 97.

34 Ibidem.

35 B.T.V. Zanten et al., "European agricultural landscapes, common agricultural policy and ecosystem services: a review" (2014) 34 Agron. Sustain. Dev. 309.

36 J. B. Ruhl, “Farms, Their Environmental Harms, and Environmental Law” (2000) 27 Ecol. Law Q. 263;

Environment Agency (n 17).

37 lbidem.

38 Ibidem.

39 N.R. Haddaway et al., "How does tillage intensity affect soil organic carbon? A systematic review" (2017) 6 Environmental Evidence 30.

40 Green et al. (n 21).

41 https://www.parliament.uk/documents/post/postpn265.pdf

42 Ruhl (n 36).

43 (n 41)

44 J.B. Bashagaluke et al., "Soil Nutrient Loss Through Erosion: Impact of Different Cropping Systems and Soil Amendments in Ghana" 13 PLoS ONE e0208250.

45 Ruhl (n 36).

46 S.S. Johannsen and P. Armitage, "Agricultural Practice and the Effects of Agricultural Land-Use on Water Quality" (2010) 28 Freshwater Forum 45.

47 F. A. Nicholson et al., "Quantifying heavy metal inputs to agricultural soils in England and Wales" (2006) 20 Water Environ J 87; U.N. Bhat and A.B. Khan, "Heavy Metals: An Ambiguous Category of Inorganic Contaminants, Nutrients and Toxins" (2011) 5 Res. J. Environ. Sci. 682.

48 Green et al. (n 21).

49 C. Su et al., "A review on heavy metal contamination in the soil worldwide: Situation, impact and remediation techniques" (2014) 3 Environmental Skeptics and Critics 24.
} 
and function, are even more vulnerable than plants. ${ }^{50}$ Microbial and enzymatic activity, which reflects soil quality, is inhibited significantly in soil with an accumulation of PTEs. ${ }^{51}$ Furthermore, enzymes in soil, which have a significant role in SOM decomposition and nutrient cycling, are reduced by increased concentration of PTEs. ${ }^{52}$ This portrays the substantial impact of unsustainable farming practices on soils.

Although soils have a great capacity to sequester $C$, whether soils act as sources or sinks of $C$ depends on their management. ${ }^{53}$ Degraded soils have a limited capacity to function and provide ES. Thus, unsustainable practices, that contribute to soil degradation generate adverse impacts on soil's capacity to reverse CC. The present study aims to scrutinise whether the existing laws protect CS by eliminating pressures on soils from agricultural practices, and where deficiencies are found, to discuss alternative approaches for protecting ES.

\section{Legal Analysis}

The European Union Common Agricultural Policy (CAP) has had a significant impact on UK agriculture over the decades. The UK had put in place CAP measures, including greening measures, cross-compliance, Rural Development Programmes (RDP). ${ }^{54}$

Greening payments, which are made to farmers who comply with mandatory practices that benefit the environment, ${ }^{55}$ contain measures related to buffer strips, landscape features, afforested areas, agroforestry, short rotation coppice. ${ }^{56}$ These can indirectly contribute to CS through preventing loss of SOM and BD. This Regulation also has an explicit reference to BD. ${ }^{57}$ Furthermore, crop diversification (cultivation of a minimum of two or three crops on arable land above a certain size) improves soil quality and is expected to contribute to $\mathrm{CS}$ and $\mathrm{BD} .{ }^{58}$ Environmentally sensitive perma-

50 Gougoulias et al. (n 13).

51 Su et al. (n 49).

52 lbidem.

53 R.J. Zomer et al., "Global Sequestration Potential of Increased Organic Carbon in Cropland Soils" (2017) 7 Scientific Reports 15554.

54 https://ec.europa.eu/info/food-farming-fisheries/key-policies/common-agricultural-policy/capglance_en

55 https:/ec.europa.eu/info/food-farming-fisheries/key-policies/common-agricultural-policy/income-support/greening_en

56 Regulation (EU) No 1307/2013 of the European Parliament and of the Council of 17 December 2013 establishing rules for direct payments to farmers under support schemes within the framework of the common agricultural policy and repealing Council Regulation (EC) No 637/2008 and Council Regulation (EC) No 73/2009 [2013] OJ L 347/608, art 46.

57 Ibidem, arts 43(3)(b), 46(5), 46(6), Annex IX.

58 G. Tamburini et al., "Agricultural diversification promotes multiple ecosystem services without compromising yield" (2020) 6 Sci. Adv. eaba1715. 
nent grassland ${ }^{59}$ can contribute to $\mathrm{CS}$ as the main objective of this measure is to afford greater protection to $\mathrm{CS}$ and $\mathrm{BD} .^{60}$

Under cross-compliance, which encourage farmers to comply with high standards for public, plant, and animal health and welfare to protect soils and maintain a variety of habitat and landscape features, ${ }^{61}$ good agricultural and environmental conditions (GAEC) measures can promote CS. ${ }^{62}$ GAEC 4 (minimum soil cover), 5 (minimum land management reflecting site-specific conditions to limit erosion) and 6 (maintenance of SOM level through appropriate practices including a ban on burning arable stubble, except for plant health reasons) standards can support this ES, as they aim to address the main issue of soil and C stock. ${ }^{63}$ However, this outcome majorly depends on how soil cover is managed. ${ }^{64}$ Moreover, GAEC 4 and 6 indirectly reduce BD loss, which can contribute to $\mathrm{CS}^{65}$ Lastly, the Regulation has a specific aim of providing information to farmers on how to improve and optimise soil C levels. ${ }^{66}$

RDP include strategies to strengthen agri-food and forestry sectors, sustainability, and wellbeing of rural areas. ${ }^{67}$ These support several ES indirectly and include a direct reference to $\mathrm{CS}^{68}$ Mainly, M1 (knowledge transfer and information actions), M2 (advisory services, farm management and farm relief services), M4 (investments in physical assets), M6 (farm and business and development), M8 (investment in the forest area development and improvement of the viability of forests), M10 (agri-environmentclimate), M11 (organic farming), M15 (Natura 2000 and Water Framework Directive), M16 (cooperation) were found beneficial for $\mathrm{CS}^{69}$ These measures are expected to address SOM and BD loss. ${ }^{70}$ As the Regulation aims to prevent erosion and improve soil management, ${ }^{71}$ farming practices which limit erosion and protect or improve the existing soil $\mathrm{C}$ are expected to enhance $\mathrm{CS}^{72}$

\footnotetext{
59 Regulation 1307/2013 (n 56), art. 45.

60 A. Frelih-Larsen et al., "Updated Inventory and Assessment of Soil Protection Policy Instruments in EU Member States" Final Report to DG Environment (February 2017)

61 https://ec.europa.eu/info/food-farming-fisheries/key-policies/common-agricultural-policy/income-support/cross-compliance_en

62 Regulation (EU) No 1306/2013 of the European Parliament and of the Council of 17 December 2013 on the financing, management and monitoring of the common agricultural policy and repealing Council Regulations (EEC) No 352/78, (EC) No 165/94, (EC) No 2799/98, (EC) No 814/2000, (EC) No 1290/2005 and (EC) No 485/2008 [2013] OJ L 347/549, arts 93, 94.

63 Ibidem, Annex II.

64 Frelih-Larsen et al. (n 60).

65 Ibidem.

66 Regulation 1306/2013 (n 62), Annex I.

67 https://ec.europa.eu/info/food-farming-fisheries/key-policies/common-agricultural-policy/ruraldevelopment_en

68 Regulation (EU) No 1305/2013 of the European Parliament and of the Council of 17 December 2013 on support for rural development by the European Agricultural Fund for Rural Development (EAFRD) and repealing Council Regulation (EC) No 1698/2005 [2013] OJ L 347/487, art. 5(5).

69 Frelih-Larsen et al. (n 60).

70 Ibidem.

71 Regulation 1305/2013 (n 71), art. 5(4)(c).

72 Frelih-Larsen et al. (n 60).
} 
CAP is found ineffective in preventing the decline of BD and ES in Europe. ${ }^{73}$ Payments, which are made only for lands in agricultural condition, led people to clear wildlife habitats. ${ }^{74}$ The policy's main goals are resilience, productive capacity of soils and maintaining soil fertility for food productivity. ${ }^{75}$ This mirrors the core issue in ES-law relationship where provisioning services with market price are prioritised over other critical yet less visible services. ${ }^{76}$ Indeed, the amount of payment that farmers receive to protect and enhance the environment is only a small proportion of CAP payments. ${ }^{77}$

Flexibility in CAP implementation is a source of compliance issues, ${ }^{78}$ whilst can appear as an opportunity that enables Member States (MS) to make the best use of policy instruments ${ }^{79}$ to achieve soil protection. ${ }^{80}$ As seen in the UK example, this opportunity is not always put into operation. ${ }^{81}$ Although the UK argues that CAP enabled a significant progress in soil protection, ${ }^{82}$ soil degradation continues with an estimated annual cost of $£ 1.2$ billion. ${ }^{83}$ Poor agricultural practices and changes in farming driven by CAP subsidies are partly responsible for this. ${ }^{84}$

Another European law with indirect impact on $\mathrm{CS}^{85}$ is the Nitrates Directive. ${ }^{86}$ This aims to reduce water pollution induced by nitrates from agricultural sources, ${ }^{87}$ and to promote good farming practices. ${ }^{88}$ Although PTEs in slurries and manures are not directly controlled, these are indirectly regulated through the limits on nutrient inputs set by the Directive, especially in Nitrate Vulnerable Zones (NVZ), ${ }^{89}$ which are waters containing a nitrates concentration of more than $50 \mathrm{mg} / \mathrm{l}$, or zones that are suscepti-

\footnotetext{
73 http://extranet.greens-efa-service.eu/public/media/file/1/5401

74 https://www.theguardian.com/commentisfree/2018/oct/10/brexit-leaving-eu-farming-agriculture

75 D. Vrebos et al., "The Impact of Policy Instruments on Soil Multifunctionality in the European Union" (2017) 9 Sustainability 407.

76 lbidem.

77 https://www.wildlifetrusts.org/sites/default/files/2018-05/wcl_future_sustainable_farming_policy_briefing.pdf

78 https://www.euractiv.com/section/agriculture-food/news/eu-agricultural-policy-incoherentand-outdated-report/

79 Frelih-Larsen et al. (n 60).

80 https://www.robert-schuman.eu/en/european-issues/0503-the-common-agricultural-policyand-the-challenge-of-subsidiarity

81 D. Helm, "Agriculture After Brexit" (2017) 33 Oxford Rev. Econ. Policy S124.

82 (n 31)

83 A.R. Graves et al., "The total costs of soil degradation in England and Wales" (2015) 119 Ecological Economics 399.

84 (n 74)

85 Vrebos et al. (n 75).

86 Council Directive 91/676/EEC of 12 December 1991 concerning the protection of waters against pollution caused by nitrates from agricultural sources [1991] OJ L 375/1 (Nitrates Directive).

87 lbidem, art 1.

88 https://ec.europa.eu/environment/water/water-nitrates/index_en.html

89 http://sciencesearch.defra.gov.uk/Default.aspx?Module=More\&Location=None\&Project ID $=16992$
} 
ble to contain such concentration unless measures are taken. ${ }^{90} \mathrm{NVZ}$ designation is for mitigating fertilisers' impact on waterbodies. ${ }^{91}$

In the Directive, accordingly, there are no soil specific targets. However, the Directive's requirement to maintain minimum levels of vegetative cover during rainy periods ${ }^{92}$ and minimise uncultivated land can address erosion. ${ }^{93}$ Lands under permanent crops improve SOM and soil structure while reducing erosion and nitrate leaching. ${ }^{94}$ The Directive also requires the implementation of soil management measures, ${ }^{95}$ which can address $\mathrm{N}$ pollution. ${ }^{96}$ Overall, minimising erosion and pollution risk, restoring soil structure and increasing SOM have positive impacts on $\mathrm{CS}^{97}$

Excessive application inorganic fertilisers disturb the $\mathrm{N}$ cycle. ${ }^{98} \mathrm{~N}$ fertilisation may increase or decrease CS depending on soil and crops. ${ }^{99}$ The effect of inorganic $\mathrm{N}$ fertilisers application on SOM is complex ${ }^{100}$ and whilst increased net primary productivity may increase the input of organic material into soils and build up SOM, the general effect of inorganic $\mathrm{N}$ fertilisation appears to be an increase in SOM mineralisation, thereby decreasing SOM levels ${ }^{101}$ and CS. By contrast, the effect of organic fertilisers is to increase SOM, which can support CS in the soil, ${ }^{102}$ but this must be balanced alongside GHG emissions by producing animals.

The Directive may also contribute to CS indirectly through promoting BD by tackling $\mathrm{N}$ pollution. However, microbial biomass and microbial respiration are reduced by inorganic $\mathrm{N}$ fertilisers, with fungal biomass is more affected than bacteria. ${ }^{103}$ This high-

\footnotetext{
90 https://ec.europa.eu/environment/water/water-framework/groundwater/framework.htm

91 R.A. Kraemer et al., "EU Soil Protection Policy: Current Status and the Way Forward" (November 2004)

92 Frelih-Larsen et al. (n 60).

93 S.R. Carpenter, "Eutrophication of aquatic ecosystems: Bistability and soil phosphorus" (2005) 102 PNAS 10002.

94 A. Mudgal et al., "Effects of long-term soil and crop management on soil hydraulic properties for claypan soils" (2010) 65 J Soil Water Conserv 393.

95 Frelih-Larsen et al. (n 60).

96 G. Louwagie et al., "The Potential of European Union Policies to Address Soil Degradation in Agriculture" (2011) 22 Land Degrad. Develop. 5.

97 R. Lal, "Beyond Copenhagen: mitigating climate change and achieving food security through soil carbon sequestration" (2010) 2 Food Security 167.

98 (n 88)

99 R. Hijbeek et al., "Fertiliser use and soil carbon sequestration: trade-offs and opportunities" (2019) (CGIAR Research Program on Climate Change, Agriculture and Food Security - Working Paper No.264); J.H. Li et al., "Fertilization with nitrogen and/or phosphorus lowers soil organic carbon sequestration in alpine meadows" (2018) 29 Land Degrad Dev 1634.

100 N.K. Mahal et al., "Nitrogen Fertilizer Suppresses Mineralization of Soil Organic Matter in Maize Agroecosystems" (2019) 7 Front. Ecol. Evol 59.

101 R.L. Mulvaney et al., "Synthetic nitrogen fertilizers deplete soil nitrogen: a global dilemma for sustainable cereal production" (2009) 38 J. Environ. Qual 2295.

102 Y. Lin et al., "Long-term manure application increases soil organic matter and aggregation and alters microbial community structure and keystone taxa" (2019) 134 Soil Biol. Biochem. 187.

103 J. Rousk et al., "Fungal and bacterial growth responses to $\mathrm{N}$ fertilization and $\mathrm{pH}$ in the 150-year, Park Grass' UK grassland experiment" (2011) 76 FEMS Microbiol. Ecol. 89.
} 
lights the need for considering all soil $\mathrm{BD}$ in setting these limits. Otherwise, protection for soil $B D$ which is crucial for capturing $C$ for a long period, remains inadequate.

The UK's compliance with the Directive is poor. ${ }^{104}$ There are farmers that apply 250 $\mathrm{N} \mathrm{ha}{ }^{-1}$ (which is allowed in non-NVZ areas) ${ }^{105}$ constituting a breach. ${ }^{106}$ In addition to poor compliance, the controls only apply where waters are at specified risks; ${ }^{107}$ thus soils and their ES are not protected from pollution in a comprehensive manner.

Another Directive with indirect impacts on $\mathrm{CS}^{108}$ is the Sewage Sludge Directive, ${ }^{109}$ which aims to encourage sludge use in agriculture whilst preventing its harmful effect on soils. ${ }^{110}$ It prohibits sludge use where the concentration of PTEs in soil exceeds the limit values ${ }^{111}$ and may impair soil quality. ${ }^{112}$ Safe sludge application on agricultural soils can support SOM content and reduce erosion while supporting soil health and $\mathrm{BD}$, ultimately promoting $\mathrm{CS} .{ }^{113}$

In theory, the Directive provides a high level of soil protection; however, its application is limited as only $\sim \%$ of UK farmland receives sludge. ${ }^{114}$ Moreover, not all harmful chemical compounds that may occur in sludge are covered, ${ }^{115}$ and some MS set the limits below the requirements for PTEs in sludge. ${ }^{116}$ The UK implemented the Directive untouched, ${ }^{117}$ and set maximum concentration limits in soils receiving sludge and maximum annual metal loading rates, ${ }^{118}$ but did not specify any limit value for PTEs in sludge. ${ }^{119}$ The associated Code of Practice provides maximum permissible concentrations of PTEs in soil after sludge application. ${ }^{120}$ Despite controls, the possibility that PTE levels in soils could increase to limit values in a relatively short time scale due to

\footnotetext{
$\overline{104}$ Louwagie et al. (n 96).

105 http://data.parliament.uk/WrittenEvidence/CommitteeEvidence.svc/EvidenceDocument/Environmental\%20Audit/Nitrate/written/77053.html

106 Louwagie et al. (n 96).

107 Frelih-Larsen et al. (n 60).

108 Vrebos et al. (n 75).

109 Council Directive 86/278/EEC of 12 June 1986 on the protection of the environment, and in particular of the soil, when sewage sludge is used in agriculture [1986] OJ L 181/6 (Sewage Sludge Directive).

110 https://ec.europa.eu/environment/waste/sludge/

111 Sewage Sludge Directive (n 109), art. 5(1).

112 Ibidem, art. 8.

113 Frelih-Larsen et al. (n 60).

114 http://randd.defra.gov.uk/Document.aspx?Document=SP0130_6422_INF.pdf

115 B.M. Cieślik et al., "Review of sewage sludge management: standards, regulations and analytical methods" (2015) 90 Journal of Cleaner Production 1.

116 V. Inglezakis et al., "European Union legislation on sewage sludge management" (2014) 23 Fresenius Environmental Bulletin 635; L. Spinosa, "Evolution of sewage sludge regulations in Europe" (2001) 44 Water Sci Technol 1.

117 B. Crathorne et al.,"Implementation of HACCP controls under the new Sludge (Use in Agriculture) Regulations" in Proceedings of CIWEM/Aqua Enviro 7th European Bio Solids and Organic Residuals Conference 2002.

118 (n 114)

119 https://ec.europa.eu/environment/archives/waste/sludge/pdf/sludge_disposal2.pdf

$120 \mathrm{https}: / /$ www.gov.uk/government/publications/sewage-sludge-in-agriculture-code-of-practice/ sewage-sludge-in-agriculture-code-of-practice-for-england-wales-and-northern-ireland
} 
sludge application exists and this is a threat to soil microbial activity, ${ }^{121}$ which is crucial for a stable $C$ reservoir. ${ }^{122}$

This analysis shows that soil protection laws discussed in this study do not offer direct and adequate protection for CS. Firstly, there is a lack of effective legislation that supports more sustainable and soil friendly farming practices. The current approach supports eternal economic growth, which tends to protect ES with market value, e.g., food and raw material. This approach is mirrored in law providing single dimensional protection for ES. The existing law is also inclined to offer a selective protection for $\mathrm{BD}$, ignoring the importance of microorganisms, bacteria or fungi for functioning soils, which exacerbates the adverse impacts of farming practices.

\section{Discussion}

The legal framework for protecting agricultural soils should include mechanisms that support sustainable practices in farming. Sustainable agriculture fosters soil health and supports BD both above and belowground to return $C$ and nutrients to soil. ${ }^{123}$ This approach is essential for CS as it includes regenerative practices, which potentially increase soil $\mathrm{C}$, such as diversifying crop rotations, planting cover crops, green manures, and perennials, ${ }^{124}$ reducing tillage frequency and depth, ${ }^{125}$ retaining crop residues $^{126}$ and eliminating synthetic chemicals. ${ }^{127}$ Natural sources of fertilisers help plants grow more roots and improve soil's capacity of $C$ storage, as increase soil microbial activity, ${ }^{128}$ whereas synthetic fertilisers result in the loss or no change in soil $C^{129}$ and encourage the dominance of bacteria that can rapidly turn ammonia into nitrate, which is easily respired or lost from the soil by leaching. ${ }^{130}$

\footnotetext{
Green et al. (n 21).

122 G. Chen et al., "Soil microbial activities and carbon and nitrogen fixation” (2003) 154 Res Microbiol 393.

123 (n 27)

124 Ibidem.

125 Johannsen and Armitage ( $\mathrm{n} 46)$

126 (n 10)

127 (n 27)

128 M.B. Peoples et al., "The Contributions of Legumes to Reducing the Environmental Risk of Agricultural Production" [in:] Agroecosystem Diversity, eds G. Lemaire et al. (Academic Press 2019); Y. Ouyang et al., "Ammonia-oxidizing bacteria are more responsive than archaea to nitrogen source in an agricultural soil" (2016) 96 Soil Biol. Biochem. 4.

129 E.D. Nafziger and R.E. Dunker, "Soil Organic Carbon Trends Over 100 Years in the Morrow Plots" (2011) 103 Agronomy Journal 261; S. Khorramdel et al., "Evaluation of carbon sequestration potential in corn fields with different management systems" (2013) 133 Soil and Tillage Research 25; M.G. Veloso et al., "High carbon storage in a previously degraded subtropical soil under no-tillage with legume cover crops" (2018) 268 Agr Ecosyst Environ 15.
}

130 Ouyang et al. (n 128). 
To successfully combat CC, law should operationalise soil friendly objectives, such as storing more $\mathrm{C}$ in soil, minimising $\mathrm{N}$ fertilisers and agrochemicals. ${ }^{131}$ Legal controls should safeguard agricultural soils, not only for the purposes of fertility, but also for other benefits, such as their capacity to store $C^{132}$

Unsustainable practices are mostly favoured, as these generally are the most economical form of production. Considering the economics of ecosystems reveals the financial outcomes of conservation initiatives. ${ }^{133}$ Decisions, in which only the market value of ES is considered, ${ }^{134}$ can be unfair, ${ }^{135}$ as the cost for protecting the nature may outweigh these benefits. ${ }^{136}$ When all the benefits provided from nature are measured, nature's value increases drastically. ${ }^{137}$ The increasing expense of CC adaptation will become an overwhelming cost, in comparison to the present cost of preserving soils and ES and will be borne by all of us and future generations. Thus, policies should encourage farmers to achieve sustainable farming objectives by introducing subsidies that support a sustainable ES approach.

Some unsustainable farming practices support the tendency for increasing economic gain by maximising production. Although food security must be achieved, a sustainable approach to soils means an inevitable decrease in yields. If we fail to take action, soils' capacity to provide yields will eventually face a drastic reduction in the long run. ${ }^{138}$ Sustainability involves an integrated management that supports economic and social improvements while protecting the environment. The former should not be prioritised at the expense of the latter. Thus, our management options should take into account the future flow of ES, ensuring that future generations benefit from the same services.

Synergies among ES mostly appear as trade-offs that occur when one service is enhanced at the expense of another. ${ }^{139} \mathrm{CS}$ is improved by converting farmlands to forests or wetlands, enhancing wildlife habitat and water quality, and increasing flood storage and recreational potential. ${ }^{140}$ However, the loss of farmlands will decrease crop

\footnotetext{
$\overline{131}$ http://data.parliament.uk/writtenevidence/committeeevidence.svc/evidencedocument/environment-food-and-rural-affairs-committee/work-of-defra-health-and-harmony/written/81967.html

132 G. Lemaire et al., "Integrated crop-livestock systems: Strategies to achieve synergy between agricultural production and environmental quality" (2014) 190 Agr Ecosyst Environ 4.

133 A. Balmford et al., "Bringing Ecosystem Services into the Real World: An Operational Framework for Assessing the Economic Consequences of Losing Wild Nature" (2011) 48 Environ Resource Econ 161.

134 I.J. Bateman et al., "Bringing Ecosystem Services into Economic Decision making: Land Use in the United Kingdom" (2013) 341 Science 45.

135 A. Balmford et al., "Economic Reasons for Conserving Wild Nature” (2002) 297 Science 950.

136 P. Sukhdev, "Putting a Price on Nature: The Economics of Ecosystems and Biodiversity" (2010) 1

The Solutions Journal 34.

137 Ibidem.

138 https://www.theguardian.com/environment/2017/oct/24/uk-30-40-years-away-eradicationsoil-fertility-warns-michael-gove

139 C. Dobbs et al., "Multiple Ecosystem Services and Disservices of the Urban Forest Establishing Their Connections With Landscape Structure and Sociodemographics" (2014) 43 Ecol. Indic. 44.

140 (n 7)
} 
production. ${ }^{141}$ If conservation lands are converted into farmlands, crop production may increase, ${ }^{142}$ diminishing wildlife, reducing water quality, and increasing $\mathrm{CO}_{2}$ emissions. ${ }^{143}$ Where trade-offs cannot be entirely avoided, the aim should be minimising the harm.

There are also win-win situations among ES. Some agricultural practices enhance SOM, BD and food production and other ES, such as CS. ${ }^{144}$ Crop rotation, cover cropping, and residue management can preserve larger amounts of $C$ in soils, ${ }^{145}$ resulting in healthy soils, counterbalanced emissions and maintained crop yields at the same time. ${ }^{146}$ These could have positive implications for long term ecological resilience, ${ }^{147}$ improved fertility status, ${ }^{148}$ food security and water holding capacity. ${ }^{149}$ This way, degraded soils can be restored, surface and ground waters can be purified, and biomass production and soil quality can improve. ${ }^{150}$ Though addressing $\mathrm{CC}$ is not possible without limiting the emissions, CS is a strong tool in this struggle ${ }^{151}$ if these win-win scenario are supported by soil management decisions.

Any decision-making process regarding ecosystems should include a step that deals with scenario development to allow selection of the best management approach in a given area, considering trade-offs and win-win situations. ${ }^{152}$ Although trade-offs are likely to occur when maximising provisioning services, these can be substantially reduced through considerate management. ${ }^{153}$ In soil management, the best option should be identified through understanding synergies among ES and impacts of farming practices, ${ }^{154}$ which requires integrating science in the process. Technical areas (identifying, measuring and valuing soil functions and ES) ${ }^{155}$ require input from several disciplines. ${ }^{156}$ Research findings must be understandable for decision-

\footnotetext{
141 Ibidem.

142 S. Glotzbach and S. Baumgärtner, "The relationship between intragenerational and intergenerational ecological justice" (2012) 21 Environ. Values 331.

143 Ibidem.

144 L.R. Boysen et al., "Trade-offs for food production, nature conservation and climate limit the terrestrial carbon dioxide removal potential" (2017) 3 Global Change Biol 30.

145 Ibidem.

146 Ibidem.

147 Zomer et al. (n 53).

148 R. Lal, "Managing Soils and Ecosystems for Mitigating Anthropogenic Carbon Emissions and Advancing Global Food Security" (2010) 60 BioScience 708.

149 S. Banwart et al., "Benefits of soil carbon: report on the outcomes of an international scientific committee on problems of the environment rapid assessment workshop" (2014) 5 Carbon Manag 185.

150 R. Lal, "Soil carbon sequestration to mitigate climate change" (2004) 123 Geoderma 1.

151 Ibidem.

152 R.S. De Groot et al., "Challenges in Integrating the Concept of Ecosystem Services and Values in Landscape Planning, Management and Decision Making" (2010) 7 Ecological Complexity 260.

153 A. Power, "Ecosystem Services and Agriculture: Tradeoffs and Synergies" (2010) 365 Phil. Trans. R. Soc. B 2959.

154 E. Barrios, "Soil Biota, Ecosystem Services and Land Productivity" (2007) 64 Ecological Economics 269.

155 B. Fisher et al., "Defining and Classifying Ecosystem Services for Decision Making" (2009) 68 Ecological Economics 643.

156 D. L. Karlen et al., "Soil Quality: A Concept, Definition, and Framework for Evaluation” (1997) 61 Soil Sci. Soc. Am. J. 4.
} 
makers, land managers and farmers, who are the ultimate stewards of soil quality and health. ${ }^{157}$ These individuals should work with researchers to investigate how specific management options affect soil $C$ levels and to test new methods for extended $C$ storage capacity. ${ }^{158}$

The role of law in safeguarding these valuable benefits involves striking a fair balance in maintaining the flow of different ES, echoing sustainability. To achieve this objective, science of ES should inform laws which in turn should aim to promote sustainable farming and to eliminate soil threats.

\section{Concluding Remarks}

Given the magnitude of the current climate crisis, combining CC adaptation and mitigation strategies is vital. This study highlighted the role of soils in CC response, which justifies the efforts for increasing the capacity of soils to sequester $C$.

This study scrutinised whether law eliminates pressures on agricultural soils whilst protecting CS. The ongoing soil degradation reduces soil functions and ES, including CS. The existing law, supporting economic growth within an unbalanced approach, fails to reflect the importance of ES for our survival.

This study highlighted legal deficiencies and discussed alternative approaches for protecting ES. Law has vast opportunities to alter the existing approach that comprises of soil destructive policies, ${ }^{159}$ through a holistic and brand-new understanding developed through the incorporation of science that allows us to comprehend the importance of nature and its services.

Soil protection should aim to expand the capacity of soils $C$ sinks and minimising soil C loss, ${ }^{160}$ reaffirming the need for storing $C$ in SOM for longer periods. Depletion of soil $C$ is accentuated by soil degradation and exacerbated by soil mismanagement. ${ }^{161}$ Sustainable soil management and farming practices have a potential to prevent $C$ loss and enhance the ability of soils to store $C .^{162}$ Thus, determining the impacts of soil management options is crucial for supporting a wide range of ES. ${ }^{163}$ Decisions regarding these options require meticulous consideration of priorities and desires. ${ }^{164}$ Rather than trade-offs among ES, the aim should be seeking win-win strategies which support for multiple ES.

\footnotetext{
157 J.W. Doran and M.R. Zeiss, "Soil Health and Sustainability: Managing the Biotic Component of Soil Quality" (2000) 15 Applied Soil Ecology 3.

158 S.D. Keestra et al., "The Significance of Soils and Soil Science Towards Realization of the United Nations Sustainable Development Goals" (2016) 2 Soil 111.

159 (n 27)

160 Olson et al. (n 12).

161 Lal (n 150).

162 Ontl and Schulte (n 9).

163 (n 7)

164 Ibidem.
} 
The capacity of soils to sequester $C$ appears to be our saviour in addressing CC. It is a natural and safe way of removing $\mathrm{CO}_{2}$ from the atmosphere and requires very little investment. ${ }^{165}$ To create a robust CC mitigation strategy through CS, the only thing we must achieve is to prevent degradation of our soils. This requires a meaningful application of ES, which will pave the way for a paradigm shift in the way environmental law protects soils.

\section{Literature}

Balmford A. et al., „Economic Reasons for Conserving Wild Nature” (2002) 297 Science 950.

Balmford A. et al., "Bringing Ecosystem Services into the Real World: An Operational Framework for Assessing the Economic Consequences of Losing Wild Nature" (2011) 48 Environ Resource Econ 161.

Banwart S. et al., "Benefits of soil carbon: report on the outcomes of an international scientific committee on problems of the environment rapid assessment workshop" (2014) 5 Carbon Manag 185.

Barrios E., ,"Soil Biota, Ecosystem Services and Land Productivity" (2007) 64 Ecological Economics 269.

Bashagaluke J.B. et al.,,,Soil Nutrient Loss Through Erosion: Impact of Different Cropping Systems and Soil Amendments in Ghana" 13 PLoS ONE e0208250.

Bateman I.J. et al., "Bringing Ecosystem Services into Economic Decision making: Land Use in the United Kingdom" (2013) 341 Science 45.

Bhat U.N. and Khan A.B., "Heavy Metals: An Ambiguous Category of Inorganic Contaminants, Nutrients and Toxins" (2011) 5 Res. J. Environ. Sci. 682.

Blouin M. et al., „A review of earthworm impact on soil function and ecosystem services” (2013) 64 Soil Sci. 161.

Boyer S. and Wratten S.D., "The Potential of Earthworms to Restore Ecosystem Services After Opencast Mining - A Review" (2010) 11 BAAE 196.

Boysen L.R. et al., „Trade-offs for food production, nature conservation and climate limit the terrestrial carbon dioxide removal potential" (2017) 3 Global Change Biol 30.

Carpenter S.R., "Eutrophication of aquatic ecosystems: Bistability and soil phosphorus" (2005) 102 PNAS 10002.

Carpenter S.R. et al., "Science for Managing Ecosystem Services: Beyond the Millennium Ecosystem Assessment" (2009) 106 PNAS 1305.

Chen G. et al., "Soil microbial activities and carbon and nitrogen fixation" (2003) 154 Res Microbiol 393.

Chen S. et al., "Plant diversity enhances productivity and soil carbon storage" (2018) 115 PNAS 4027.

Cieślik B.M. et al., "Review of sewage sludge management: standards, regulations and analytical methods" (2015) 90 Journal of Cleaner Production 1.

Clapperton J., "Managing the Soil as a Habitat" (2006) Proceedings of the 2006 Indiana CCA Conference https://www.agry.purdue.edu/cca/2006/pdf/clapperton.pdf

165 Lal (n 150). 
Crathorne B. et al., "Implementation of HACCP controls under the new Sludge (Use in Agriculture) Regulations" in Proceedings of CIWEM/Aqua Enviro 7th European Bio Solids and Organic Residuals Conference 2002.

De Groot R.S. et al., "Challenges in Integrating the Concept of Ecosystem Services and Values in Landscape Planning, Management and Decision Making" (2010) 7 Ecological Complexity 260.

De Vries F.T. et al., "Soil food web properties explain ecosystem services across European land use systems" (2013) 110 PNAS 14296.

Dobbs C. et al., "Multiple Ecosystem Services and Disservices of the Urban Forest Establishing Their Connections With Landscape Structure and Sociodemogrphics" (2014) 43 Ecol. Indic. 44.

Doran J.W. and Zeiss M.R., "Soil Health and Sustainability: Managing the Biotic Component of Soil Quality" (2000) 15 Applied Soil Ecology 3.

Fisher B. et al., "Defining and Classifying Ecosystem Services for Decision Making” (2009) 68 Ecological Economics 643.

Franco A.J. et al., "Linking soil engineers, structural stability, and organic matter allocation to unravel soil carbon responses to land-use change" (2020) 150 Soil Biol. Biochem. 107998.

Frelih-Larsen A. et al., "Updated Inventory and Assessment of Soil Protection Policy Instruments in EU Member States" Final Report to DG Environment (February 2017).

Glotzbach S. and Baumgärtner S., "The relationship between intragenerational and intergenerational ecological justice" (2012) 21 Environ. Values 331.

Gougoulias C. et al., "The role of soil microbes in the global carbon cycle: tracking the belowground microbial processing of plant-derived carbon for manipulating carbon dynamics in agricultural systems" (2014) $94 \mathrm{~J} \mathrm{Sci} \mathrm{Food} \mathrm{Agric} 2362$.

Graves A.R. et al.,"The total costs of soil degradation in England and Wales” (2015) 119 Ecological Economics 399.

Green I. et al., "Accumulation of Potentially Toxic Elements in Agricultural Soils" [in:] Environmental Loss and Damage in a Comparative Law Perspective: Attribution, Liability, Compensation and Restoration, eds B. Pozzo and V. Jacometti (Intersentia, Cambridge 2020).

Haddaway N.R. et al., "How does tillage intensity affect soil organic carbon? A systematic review" (2017) 6 Environmental Evidence 30.

Helm D., "Agriculture After Brexit" (2017) 33 Oxford Rev. Econ. Policy S124.

Hijbeek R. et al., "Fertiliser use and soil carbon sequestration: trade-offs and opportunities" (2019) (CGIAR Research Program on Climate Change, Agriculture and Food Security - Working Paper No. 264).

Inglezakis V. et al., "European Union legislation on sewage sludge management" (2014) 23 Fresenius Environmental Bulletin 635.

Johannsen S.S. and Armitage P., "Agricultural Practice and the Effects of Agricultural Land-Use on Water Quality" (2010) 28 Freshwater Forum 45.

Karlen D.L. et al., "Soil Quality: A Concept, Definition, and Framework for Evaluation" (1997) 61 Soil Sci. Soc. Am. J. 4.

Keestra S.D. et al., "The Significance of Soils and Soil Science Towards Realization of the United Nations Sustainable Development Goals" (2016) 2 Soil 111.

Khorramdel S. et al., "Evaluation of carbon sequestration potential in corn fields with different management systems" (2013) 133 Soil and Tillage Research 25. 
Kraemer R.A. et al., "EU Soil Protection Policy: Current Status and the Way Forward" (November 2004).

Lal R., "Beyond Copenhagen: mitigating climate change and achieving food security through soil carbon sequestration" (2010) 2 Food Security 167.

Lal R., "Managing Soils and Ecosystems for Mitigating Anthropogenic Carbon Emissions and Advancing Global Food Security" (2010) 60 BioScience 708.

Lal R., "Managing soils for negative feedback to climate change and positive impact on food and nutritional security" (2020) 66 Soil Sci Plant Nutr 1.

Lal R., "Soil carbon sequestration to mitigate climate change" (2004) 123 Geoderma 1.

Lemaire G. et al., "Integrated crop-livestock systems: Strategies to achieve synergy between agricultural production and environmental quality" (2014) 190 Agr Ecosyst Environ 4.

Li J.H. et al., "Fertilization with nitrogen and/or phosphorus lowers soil organic carbon sequestration in alpine meadows" (2018) 29 Land Degrad Dev 1634.

Louwagie G. et al., "The Potential of European Union Policies to Address Soil Degradation in Agriculture" (2011) 22 Land Degrad. Develop. 5.

Mahal N.K. et al., "Nitrogen Fertilizer Suppresses Mineralization of Soil Organic Matter in Maize Agroecosystems" (2019) 7 Front. Ecol. Evol 59.

Malik A.A. et al., "Soil Fungal: Bacterial Ratios Are Linked to Altered Carbon Cycling" (2016) 7 Front. Microbiol. 1247.

Midgley G.F. et al., "Terrestrial carbon stocks and biodiversity: Key knowledge gaps and some policy implications" (2010) 2 Curr Opin Environ Sustain 264.

Monbiot G., "The one good thing about Brexit? Leaving the EU's disgraceful farming system" (The Guardian, 10 October 2018), https://www.theguardian.com/commentisfree/2018/oct/10/ brexit-leaving-eu-farming-agriculture

Moyer J. et al., "Regenerative Agriculture and the Soil Carbon Solution” (Rodale Institute, September 2020), https://rodaleinstitute.org/education/resources/regenerative-agriculture-andthe-soil-carbon-solution

Mudgal A. et al., "Effects of long-term soil and crop management on soil hydraulic properties for claypan soils" (2010) 65 J Soil Water Conserv 393.

Mulvaney R.L. et al., "Synthetic nitrogen fertilizers deplete soil nitrogen: a global dilemma for sustainable cereal production" (2009) 38 J. Environ. Qual 2295.

Nafziger E.D. and Dunker R.E., "Soil Organic Carbon Trends Over 100 Years in the Morrow Plots" (2011) 103 Agronomy Journal 261.

Nicholson F.A. et al., "Quantifying heavy metal inputs to agricultural soils in England and Wales" (2006) 20 Water Environ J 87.

Nunes F.C. et al., "Soil as a complex ecological system for meeting food and nutritional security" [in:] Climate Change and Soil Interactions, eds M.N.V. Prasad and M. Pietrzykowski (Elsevier 2020).

Olson K.R. et al., "Experimental Consideration, Treatments, and Methods in Determining Soil Organic Carbon Sequestration Rates" (2014) 78 Soil Sci Soc Am J 348.

Ontl T.A. and Schulte L.A., "Soil Carbon Storage” (2012) 3 Nature Education Knowledge 35.

Ouyang Y. et al., "Ammonia-oxidizing bacteria are more responsive than archaea to nitrogen source in an agricultural soil" (2016) 96 Soil Biol. Biochem. 4.

Pe'er G. et al., "Is the CAP Fit for purpose? An evidence-based fitness-check assessment" (November 2017), http://extranet.greens-efa-service.eu/public/media/file/1/5401 
Peoples M.B. et al., "The Contributions of Legumes to Reducing the Environmental Risk of Agricultural Production" [in:] Agroecosystem Diversity, eds G. Lemaire G et al. (Academic Press 2019).

Posthumus H. et al., "Soil conservation in two English catchments: Linking soil management with policies" (2011) 22 Land Degrad. Develop. 97.

Power A., "Ecosystem Services and Agriculture: Tradeoffs and Synergies" (2010) 365 Phil. Trans. R. Soc. B 2959.

Pribyl D.W., "A critical review of the conventional SOC to SOM conversion factor" (2010) 156 Geoderma 75.

Raudsepp-Hearne C. et al., "Ecosystem Service Bundles for Analyzing Tradeoffs in Diverse Landscapes" (2010) 107 PNAS 5242.

Rousk J et al., "Fungal and bacterial growth responses to $\mathrm{N}$ fertilization and $\mathrm{pH}$ in the 150-year 'Park Grass' UK grassland experiment' (2011) 76 FEMS Microbiol. Ecol. 89.

Ruhl J.B., “Farms, Their Environmental Harms, and Environmental Law" (2000) 27 Ecol. Law Q. 263.

Rui Y. et al., "Microbial respiration, but not biomass, responded linearly to increasing light fraction organic matter input: Consequences for carbon sequestration" (2016) 6 Scientific Reports 35496.

Six J. et al., "Bacterial and Fungal Contributions to Carbon Sequestration in Agroecosystems" (2006) 70 Soil Sci Soc Am J 555.

Spinosa L., "Evolution of sewage sludge regulations in Europe” (2001) 44 Water Sci Technol 1.

Su C. et al., "A review on heavy metal contamination in the soil worldwide: Situation, impact and remediation techniques" (2014) 3 Environmental Skeptics and Critics 24.

Sukhdev P., "Putting a Price on Nature: The Economics of Ecosystems and Biodiversity" (2010) 1 The Solutions Journal 34.

Tamburini G. et al., "Agricultural diversification promotes multiple ecosystem services Veloso M.G. et al.,"High carbon storage in a previously degraded subtropical soil under no-tillage with legume cover crops" (2018) 268 Agr Ecosyst Environ 15.

Vrebos D. et al., "The Impact of Policy Instruments on Soil Multifunctionality in the European Union" (2017) 9 Sustainability 407.

Weissengruber L. et al., "Long-term soil accumulation of potentially toxic elements and selected organic pollutants through application of recycled phosphorus fertilizers for organic farming conditions" (2018) 110 Nutr. Cycling Agroecosyst. 427.

Wen Y. et al., "Impact of agricultural fertilization practices on organo-mineral associations in four long term field experiments: Implications for soil C sequestration" (2019) 651 Sci Total Environ 591.

White S., "EU agricultural policy incoherent and outdated - report" (EURACTIV, 4 December 2017), https://www.euractiv.com/section/agriculture-food/news/eu-agricultural-policyincoherent-and-outdated-report/

Wildlife \& Countryside Link, "A Future Sustainable Farming and Land Management Policy for England" (2018), https://www.wildlifetrusts.org/sites/default/files/2018-05/wcl_future_sustainable_farming_policy_briefing.pdf

Yang Y. et al., "Soil carbon sequestration accelerated by restoration of grassland biodiversity" (2019) 10 Nature Communications 718.

Zanten B.T.V. et al., "European agricultural landscapes, common agricultural policy and ecosystem services: a review" (2014) 34 Agron. Sustain. Dev. 309. 
Zomer R.J. et al., "Global Sequestration Potential of Increased Organic Carbon in Cropland Soils" (2017) 7 Scientific Reports 15554.

\section{Summary}

\section{Merve Demir, lain Green, Tilak Ginige}

\section{Effectiveness of the United Kingdom Soil Protection Laws in Protecting the Ecosystem Service of Carbon Sequestration}

Carbon is crucial for life and exists in various reservoirs, such as plant tissues, soil organic matter, geology, and atmosphere. There is a direct relationship between carbon dioxide $\left(\mathrm{CO}_{2}\right)$ levels in the atmosphere and rising temperatures. $\mathrm{CO}_{2}$ is removed from the atmosphere and stored in ecosystems. Carbon sequestration (CS) - the process of capturing and storing atmospheric $\mathrm{CO}_{2}$ - and expanding $\mathrm{C}$ storage of soils are appealing climate change (CC) responses. Agricultural soils are one of the largest $C$ reservoirs and have potential for extended CS. Thus, protecting this ecosystem service (ES) we obtain from soils is crucial for addressing CC. Soil protection legislation should incorporate the significance of CS.

The key issues in the sphere of natural resources can only be addressed by utilizing natural sciences in legal arguments. Accordingly, this study begins with highlighting the importance of soils for CS from a natural science perspective. This study analyses soil protection laws in the UK by scrutinizing whether they eliminate pressures on agricultural soils in a way that protect CS. The findings of this study suggest that soil protection laws do not offer a satisfactory protection for CS. We conclude by discussing alternative approaches for protecting CS in an effective manner and reverse the current trends in ES protection.

Keywords: carbon sequestration; climate change; ecosystem services; soil protection.

\section{Streszczenie}

\section{Merve Demir, Iain Green, Tilak Ginige}

\section{Skuteczność brytyjskich przepisów dotyczących ochrony gleby w ochronie usług ekosystemowych sekwestracji węgla}

Węgiel ma kluczowe znaczenie dla życia i występuje w przyrodzie w różnych formach, takich jak tkanki roślinne, materia organiczna gleby, geologia i atmosfera. Istnieje bezpośredni związek między poziomem dwutlenku węgla (CO2) w atmosferze a wzrostem temperatury. CO2 jest usuwany z atmosfery i magazynowany w ekosystemach. Sekwestracja węgla (CS) - proces wychwytywania i przechowywania atmosferycznego $\mathrm{CO} 2$ - oraz rozszerzanie się magazynowania węgla w glebach są jedną z form reakcji na wyzwania związane ze zmianami klimatu. Gleby rolnicze są jednym z największych zbiorników węgla i mają potencjał dla rozszerzonej jego sekwestracji. Tak więc ochrona tej usługi ekosystemowej, którą uzyskujemy z gleby, ma kluczowe znaczenie dla adaptacji zmian klimatu. Prawodawstwo dotyczące ochrony gleby powinno uwzględniać znaczenie sekwestracji węgla. 
Kluczowe kwestie w sferze zasobów przyrodniczych mogą być rozwiązane jedynie poprzez wykorzystanie dorobku nauk przyrodniczych w argumentacji prawniczej. W związku z tym niniejsze badanie rozpoczyna się od podkreślenia znaczenia gleb dla sekwestracji węgla z perspektywy nauk przyrodniczych. Niniejsze badanie analizuje przepisy dotyczące ochrony gleby w Wielkiej Brytanii, sprawdzając, czy eliminują one presję na gleby rolnicze w sposób, który chroni usługi sekwestracji. Wyniki tego badania sugerują, że przepisy dotyczące ochrony gleby nie zapewniają zadowalającej ochrony tej funkcji. Na zakończenie omawiamy alternatywne podejścia do skutecznej ochrony sekwestracji węgla i proponujemy rozwiązania mające na celu odwrócenie obecnych trendów w ochronie usług ekosystemowych.

Słowa kluczowe: sekwestracja węgla; zmiana klimatu; usługi ekosystemowe; ochrona gleby. 